Canadian University Music Review

Canadian University Music Review

Revue de musique des universités canadiennes

Elaine Barkin and Lydia Hamessley, eds. 1999. Audible Traces: Gender, Identity, and Music. Zurich: Carciofoli Verlagshaus. Verbal score, index, CD, 292 pp. ISBN 3-905323-00-1 (hardcover)

Tullia Magrini, ed. 2003. Music and Gender: Perspectives from the Mediterranean. Chicago: University of Chicago Press, 371 pp. ISBN 0226501655 (hardcover)

\title{
Beverley Diamond
}

Volume 24, numéro 1, 2003

URI : https://id.erudit.org/iderudit/1014676ar

DOI : https://doi.org/10.7202/1014676ar

Aller au sommaire du numéro

Éditeur(s)

Canadian University Music Society / Société de musique des universités canadiennes

ISSN

0710-0353 (imprimé)

2291-2436 (numérique)

Découvrir la revue

Citer ce compte rendu

Diamond, B. (2003). Compte rendu de [Elaine Barkin and Lydia Hamessley, eds. 1999. Audible Traces: Gender, Identity, and Music. Zurich: Carciofoli Verlagshaus. Verbal score, index, CD, 292 pp. ISBN 3-905323-00-1 (hardcover) / Tullia Magrini, ed. 2003. Music and Gender: Perspectives from the Mediterranean. Chicago: University of Chicago Press, 371 pp. ISBN 0226501655 (hardcover)]. Canadian University Music Review / Revue de musique des universités canadiennes, 24(1), 118-125. https://doi.org/10.7202/1014676ar

All Rights Reserved (C Canadian University Music Society / Société de musique des universités canadiennes, 2005
Ce document est protégé par la loi sur le droit d'auteur. L’utilisation des services d'Érudit (y compris la reproduction) est assujettie à sa politique d'utilisation que vous pouvez consulter en ligne.

https://apropos.erudit.org/fr/usagers/politique-dutilisation/ 
Despite these shortcomings, my ultimate assessment is closer to the highly positive tone with which I opened this review. Cumming has achieved a unique and impressive synthesis of music theory, semiotics, aesthetics, and philosophy. She has crafted a theoretical perspective which is complex and subtle while remaining approachable, and has deftly applied it to one of the most important questions in current musicological debate: how are subjectivities constructed through music, both as text and as practice? I would strongly encourage anyone with an interest in such questions to read this book as soon as possible.

\section{REFERENCE}

Cumming, Naomi. 1997. "The Subjectivities of 'Erbarme Dich'." Music Analysis 16, no. 1: 5-44.

William Echard

Elaine Barkin and Lydia Hamessley, eds. 1999. Audible Traces: Gender, Identity, and Music. Zurich: Carciofoli Verlagshaus. Verbal score, index, CD, 292 pp. ISBN 3-905323-00-1 (hardcover).

Tullia Magrini, ed. 2003. Music and Gender: Perspectives from the Mediterranean. Chicago: University of Chicago Press, 371 pp. ISBN 0226501655 (hardcover).

In the last five years, several new anthologies on gender and music have appeared, each extending the issues and approaches of this important sub-field of music scholarship. This review explores two collections that are innovative in dramatically contrasting ways. While, at the end of my close reading of the two books, I think the Magrini will have a greater impact, the Barkin / Hamessley volume will also inform my future reading lists.

Audible Traces: Gender, Identity, and Music by Barkin and Hamessley is arguably the book that risks the most in its unmodified celebration of "experience" and its presentation of multiple modes of representation, including composers' personal accounts, poetry, diary entries, and a "score" with audio on the accompanying $\mathrm{CD}$. There has been a tendency to move away from such forms of experimentation in the past few years and hence this volume may represent an experimental moment the significance of which will echo differently for different reader/listeners. I really enjoyed the diverse writing styles.

The insistence on individual diversity, indeed in some articles the downplaying of groupness, including, in some cases, any acknowledgement of a priori gender consciousness, is a further characteristic, one that contrasts with the Magrini anthology that is reviewed below. Is this a new form of denial for the social groundedness of artistic practices, or is it an antidote to some overly deterministic accounts of gender, class, and race? This particular insistence on individuality is perhaps related to the fact that the book is a collaboration between a musicologist and a composer; indeed, composers' voices are quite 
prominent. The bridging of the creative and scholarly worlds is a welcome direction in gender studies. The anthology also endeavours to bridge from the world of Euro-American classical music to other worlds: dance (Cook, Mockus), popular music (Cusick, Hisama, Morris, Coulombe), and non-Western music (only Zheng).

Perhaps like other multi-authored compilations that have a strong focus on individual identity, this one comes across like an assembly of shards-the "traces" of the title, bits and pieces, with surprising but unplanned resonances. The editors intend this effect arguing for the "real-time processes" (Barkin) of thought, for its unconscious and yet significant associations evident only if intention and control are given lower priority. I find that my response to this is equivocal. On one hand, the writing is self-indulgent, in the same way a rehearsal presented as a final performance would be, or a first draft published without editing. On the other, the process is of considerable interest to some, even if the strength of the message is compromised. Hamessley makes a valiant attempt to draw meaning out of the miscellany in her fine introduction. Using the metaphor of a quilt (indeed a piece of her work as a quilter is used as the cover art and is also replicated as figure 1), she reminds us that the assembling of pieces is, in itself, a means of creating pattern. She suggests that the mirroring of the symbolic "blocks" in this collection reveals a repeated emphasis on acoustic spaces, abundant bodies, bodies performing music, embodied voices, racial reflections, musicians as others, contrasts between representation and endorsement, story-telling, the significance of changes in context, and the role of interpretive communities. It's a long list but a fair account of the themes of significance.

I would like to carry the quilting metaphor a bit further. While the anthology may have done the piecing, the careful arrangement of fabric textures, colours and design, it has done very little quilting - the overlay of stitched pattern to highlight pattern or counterpoint the design of the pieces with a new layer of imagery. That additional layer would, in the case of an academic book, be a stronger emphasis on interpretive frameworks, theoretical underpinnings, and definitions of frequently invoked concepts such as identity and experience. Consider the introductory forum on "composing women" in which eight women composers were asked to respond to the question: "How do you go about doing whatever it is you consider to be your work?" Predictably, they answered the question in completely different, albeit fascinating, ways. Since e-mail was the mode for this "forum," why not have had them converse with one another, developing themes and insights from their initial presentation of self? As it is, their short statements are assumed to be self-evident and natural; left without commentary, they have less impact and utility than they might have had. At the other end of the anthology, distinguished music theorist Benjamin Boretz offers an extended aesthetic riff on "Music Consciousness Gender" in both print and audio (CD) formats. Curiously, the one male voice is (once again) privileged as the only audible trace in this publication. While he quotes Mary Lee Roberts at one point, it would have been satisfying to hear something more of the work of the other women composers who participated in 
the Composer's Forum, rather than hear only one quoted in this pseudo-e-e-cummings, stream-of-consciousness exercise.

Individual experience as a factor that impacts on scholarship is more successfully highlighted by a number of authors: Kielian-Gilbert's multiperspectival analysis of Rebecca Clarke's Sonata for Viola and Piano, Cook's interweaving of her own relationship to dance with her historical account of Vernon and Irene Castle, Morris's exploration of the post-Stonewall bonding of gay men and large African American women in the context of disco culture of the early 80 s, Coulombe's exploration of Riot Grrrls, and Barkin's reflections (as the wise elder?) on the distinctions between real-time processes (aging for instance) and real-time output. These pieces have more productive but not uniform impacts, in my view. To see personal experience factored into analysis, as Kielian-Gilbert does, is to give permission to listeners: to offer them the possibility of several metaphorical processes of musical reading. Agency is not always clear in these readings. Who, exactly, is the ideal and actual listener? But music as a series of conversations that we have with the texts of composers-this remains a powerful idea for me. Morris's buoyant writing about music and sexuality is always engaging. It has an "I was here and this is how it was" quality that reaches the ethnographer in me. But in this particular article we also see a creative attempt to look at musical phrase structures as expectation, in order to look at the construction of intersubjective relationships through sound. Like Morris, Coulombe ventures into power relations, into questions about violent attitudes and behaviour, and theories of rage as cathartic in relation to the southern California blues artist, Caneye Kane. By addressing the confusing messages of feminism, she also presents a less idealized picture of American culture than many other authors in this anthology.

Perhaps the most effective piece in the anthology is Susan Cook's examination of Irene and Vernon Castle. She positions her work as a challenge to musicology's dismissal of the dancing body. Her challenge involves an invocation of a Grimm's fairy tale and candid stories of her own dancing body. As she unfolds how the Castles' story reflects relations among races and classes, we see the body as politicized in all three of her narrative levels. It is a brilliant interwoven tale.

Other essays in this anthology focus more on musical interpretation, most often with an "alternative" slant. Hence, Martha Mockus suggests a reexamination of Pauline Oliveros "in the company of women" (particularly dancer Paula Josa-Jones) rather than as the lone woman among modernist men. She keeps the focus on the body, exploring the connotations of skin, considering the accordion (Oliveros's instrument) as an amplification of the lung. Cusick shifts the interpretive lens by querying the very distinction between speech and song. The intelligibility of the latter is determined deeper in the body. She explores this intelligibility with reference to selected pop performances by Pearl Jam's Eddie Vedder and by the Indigo Girls. Less deeply informed by historical research than much of their other work, both Hisama's and Cusick's homologies between the body's vocal production and social constructs are intriguing but would be more convincing with further contextualization (in 
relation to the genres of popular music, in relation to concepts of social relationship, in relation to concepts about the body itself).

Two essays extend the rather rich domain of feminist opera criticism. Rabinowitz reads Carmen as more heroic than recent feminist critics have tended to do; he offers, in particular, an alternative to McClary's interpretation of Carmen (1992). Similarly Lochhead reviews divergent readings of Lulu in Berg's eponymous opera. She asks important questions of whether we are attempting to move toward a right interpretation but implicitly her reading is put forward as the most authoritative, at least for the late twentieth century. For me, the factors that shape each divergent reading are by far the most interesting issue.

One essay doesn't fit very well with others in the volume. Su Zheng focuses on the inconsistencies between a given society's gender ideology and the gendering of its music. With reference to four historically situated examples of Chinese music, she demonstrates redefinitions of woman as ambivalent, as "other," or both. Unfortunately, because this is the only non-Western article, it is positioned by the editors simply to represent the fact that Western theory doesn't explain everything. That is, Zheng's work is simply the historic "Other." This is truly an unfortunate implication.

In sum, then, this anthology offers us an important bridging of the aesthetic and the scholarly. A welcome diversity of approaches awaits the individual who takes this from the shelf: writing from the perspective of composer or musicologist, combinations of auto-ethnography and historical research, print and audio. There is some unevenness, as there inevitably is in this sort of publication, and there is quite a lot of material that begs for further contextualization and interpretation. But the very fact that meanings are elusive makes it a valuable pedagogical tool.

The anthology edited by Tullia Magrini is a significant departure from the Barkin and Hamessley approach. It constitutes a welcome exploration of music and gender in a region where the complexity of sociocultural (religious, national, ethnic, gendered) diversity is extreme.The historical approach to gender in this area has been one social dimension that an earlier generation of scholars such as Julian Pitt-Rivers and John Peristiany (1992) reduced to a rather simple formula of (male) honour and (female) shame. Various scholars have critiqued the reductionism of this paradigm but, until now, we have not had, in a single volume, studies that demonstrate how music is central to a less reductionist understanding. The "Mediterranean," then, challenges scholars to deal with hybridity, as well as conflict generated by boundary making. It requires researchers to deal with big categories - the West and the East, or Islam-Judaism-Christianity-and to see not how they have been separated but how they have interacted historically and currently, through the gendered practices of music. The regional focus facilitates a deeply informed picture to emerge, within and among the fifteen studies here. The inbetween of the studies-the ways in which comparison is implicit but conditioned by infor- 
mation about different contexts or individual agencies-is one of the rich rewards of reading this book. Would that all anthologies were as interwoven as this one. Tullia Magrini deserves high commendation for organizing the seminar in 1998 that inaugurated discussion among these scholars, for continuing that discussion on-line (mostly on the web journal, Music and Anthropol$o g y$ ), and delivering this print publication to us.

In her introduction, Magrini outlines her aim to get past the recovery of women's music to explorations of music as gendered culture, a concept that includes audiences and performers as well as creators. She outlines her own work on the very different social contexts and motivations that condition the singing of ballads by men and women in northern Italy. She moves to the rules of interaction governing dance movements, to instances of cross-appropriation, unorthodox individuals, and concepts of transgression that challenge gender segregated traditions, and to the need to historicize the representations of gender and music in the Mediterranean. As others have done, she challenges the reductionism of the honour-shame paradigm and the implication that the Mediterranean is a "culture area" with some degree of homogeneity. Rather she bounds the concept of the Mediterranean simply as a region in which there have been exceedingly diverse cultures with 6,000 years of shared history; their hybridity but also their strongly localized practices prefigure globalization.

While Magrini states that the first three articles examine male and female roles in the development of genres, I suggest that the relationality of the genres is the key point here. Gender systems are defined by the totality of musical genres, not by specific ones. The most successful in this regard are the articles by Bithell and Sugarman. Bithell's study of changing dynamics of gender relations in various song genres of Corsica is a good complex description, informed by a detailed knowledge of archival sources. This enables her to identify women who defied norms and to trace historical changes in performance practice. She focuses mainly on three genres: the polyphonic pagjhella and chjam'è rispondi (public debates), both of which are performed by men in ways that challenge stereotypes of men as bandits and outlaws, and the improvised female laments that demonstrate women's concern with honour (the inverse of the stereotype). She analyzes why the men's genres have been more resistant to modernization than the women's. Labajo's work on flamenco, particularly Roma stereotypes, raises questions about transvestite performance and offers hints about nationalism. Sugarman argues explicitly that the Prespa Albanian gender structures cannot be understood with a single genre focus but through genre comparison. In this case she looks at the traditional line dance and the genre of çoçek (a synthesis of elements from Middle Eastern solo dancing, Roma wedding band tunes, and Turkish music) as a means of contesting images of respectability and eroticism. There is a nice compilation of nineteenth-and early twentieth-century data here, again emphasizing historical change. Her compelling demonstration that genres derive meaning from their juxtaposition with other genres suggests an important new direction in music and gender studies. 
Silverman, Plastino and Pettan focus directly on the Roma. Carol Silverman introduces the concept of "hypersexualization" as she unfolds the performance strategies of Balkan Muslim Roma singer, Esma Redzepova. This one woman's story not only tells us how she as an individual resisted social norms, but uncovers the ways in which sexuality, marginalization, and market place intersect and influence the gendered career decisions of musicians. Plastino's focus is on dance; three ethnographic descriptions are vivid although I would have liked some detail about music. I was left wondering why he uses the outmoded label "Gypsy" instead of Roma which is preferred by other authors in the volume. Pettan questions the binaries by exploring three musical practices of Roma in Kosovo that blur gender dichotomies: the use of a copper pan as an accompaniment to singing, a practice that he thinks relaxed the gender rules since the pan replaced the male associated gusle (bowed lute); the music of sworn virgins (women living as men); and the more recent development of talava, a genre in which men that he describes as "alleged homosexuals" perform female repertoire but with electronic amplification.

A number of studies focus on popular music. Holst-Warhaft considers the "shady ladies" of rebetika, arguing (again) that close attention to performance challenges the classic honour-shame paradigm. Important dimensions of her interpretation are her consideration of parody, particularly with regard to her exploration of the homoerotic. Focusing on the pre-war star Roza Eskenazi as well as the post-war, openly gay singer Sotiria Bellou, she teases out the implication of the shift from underclass venues such as hashish dens in which occasional participation by women was admired, to postwar, "respectable" bouzouki clubs where women have less status. Virolle's exploration of Algerian rai, a genre (like rebetika) in which women played a significant early role but have been absent from newer phases, again stresses that changes in gendered practices are congruent with new contexts. She looks at changes in performance venue but also the "not coincidental" opening of the country toward democratic principles. Like Silverman, Holst-Warhaft, and Stokes, she focuses on one exceptional individual, Cheikha Rimitti. Stokes leans more heavily toward theorization as he explores "how musicians are involved in the production of cultural intimacy in evolving nation states"-specifically Turkey. Like Holst-Warhaft, he looks at the self-representation and life experiences of two artists of different generations. Zeki Müren embraced arabesque at a period when it was controversial; he was ambivalent about his own sexual orientation (although Stokes tells us that his mostly female fan base largely regarded him as gay), and was committed to the project of nation building. The transgendered singer Bulent Ersoy, on the other hand, is detached from the national project and illustrates to Stokes the "futility of the gendered code." But as he describes their lives he uses the prefix "hyper" (hyper-normativity, hyper-gender) a number of times and implicitly signals that there is a normalized perspective, a code if you will, that remains deeply influential for these individuals. Their "hyper" gender constructs may "exceed" but are so-described in relation to normalized social expectations. 
Several papers address unique topics. Seroussi's exploration of the role of Sephardic women in collecting and writing about Sephardic song counters the stereotype of Jewish women as less literate than men. Just as several other studies point to different motives for performing a similar repertoire, this essay asserts different motives for male and female collecting; the women strove to aid memory and to become the cultural archivists. Both Brint Joseph and Kapchan study Moroccan society. The former paper explores social criticism in the love songs of Riffian Berber women, suggesting they have more agency in their choice of partners than they are generally thought to have. The latter allegedly uses a phenomenological approach although this seems merely to imply that field notes are incorporated. Kapchan looks at the concept of nashat - a state of animation, vitality, excess-as she has seen it in various contexts of women's performance.

Most of the case studies in the anthology reference religious values and customs, but for Nieuwkerk and Bohlman, religion is the central subject. Nieuwkerk looks at the very interesting phenomenon of born-again Muslim performers, comparing the discourse of stars and "non-stars"- the latter, a rather elusive and broad category. Bohlman takes on the sacred in a wide ranging comparative paper that serves as the book's end piece. He argues that sacred spaces defy the binaries of male and female, particularly in the Mediterranean. The factors to which he points are narrativity (the translation of sacred texts through intermediaries in all of the religions of the region), shrines (especially dense in the Mediterranean area and often having idiosyncratic rules), journeying (where new genderings often occur), and intense contexts of war and peace. His generalizations are big ones-as big, perhaps, as the honour-shame paradigm of his predecessors - and his examples move from the secular rai that developed in tandem with the growth of Islam, to the apparitions of the virgin at Medjugorge in Bosnia Herzogovinia. The paper is more thought provoking than compelling in its argument perhaps. An excellent way to end the anthology, in my view.

\section{COMPARING THE APPROACHES TO GENDER AND MUSIC}

Reading these two volumes back-to-back raised for me many questions about the way we bracket research on music and gender. While the editors of both anthologies were invested in challenging the inadequate binaries of masculine and feminine, they did so in very different ways. Barkin and Hamessley, and most of "their" authors, emphasized the individual, arguably moving away from a critique of social constructs. They could do this by focusing on rather privileged individuals-composers in the North American academy or successful pop musicians, for instance. The authors whose work Magrini assembled also frequently introduce outstanding individual artists, often ones who defied gender constructs in their societies, but their stories are contextualized historically and ethnologically. The stress on performance and the ethnographic method implied by that emphasis generally keeps the individual and social constructs of gendered selfhood in the picture at the same time, as they 
necessarily are in life. We learn more deeply about music and gender by seeing how practices changed in new contexts, how new forms of religion or governance seemed to parallel shifts in musical practices, and how class and racial attitudes had necessarily to be considered in the career decisions of musicians. These stories are peopled with both privileged and unprivileged musicians. Furthermore, many of the most compelling essays refuse to look at a single genre, arguing that gender constructs are often structured relationally in systems whereby one musical genre derives meaning from others. This anthology is rich not only in information but also in theoretical potential, in my view.

\section{REFERENCES}

McClary, Susan. 1992. George Bizet: Carmen. Cambridge: Cambridge University Press.

Pitt-Rivers, Julian, and John Peristiany. 1992. Honor and Grace in Anthropology. Cambridge Studies in Social and Cultural Anthropology, no. 76. Cambridge: Cambridge University Press.

Beverley Diamond

David Kopp. 2002. Chromatic Transformations in Nineteenth-Century Music. Cambridge: Cambridge University Press. xiii, 275 pp. ISBN 0-521-80463-9 (hardcover).

David Kopp's study of chromatic mediant relations is clearly laid out and well presented. After two introductory chapters, he summarizes how other theorists have treated the topic of chromatic third-relations (chap. 3-6); he outlines his own analytic methodology (chap. 7); and he provides relevant analyses (chap. 8-9). Kopp provides an extensive bibliography for approaches to theories of nineteenthcentury harmonic practice. He indicates that in recent theoretic models, "the line of inquiry in tonal transformation theory seems to be shifting its focus ... from theory of harmony per se toward [transformational] models based on voice-leading," while his model presents "a transformational system based on common-tone tonality" (p. 165). Kopp's emphasis will be on harmonic function and root relations. ${ }^{1}$

In chapter 1, Kopp presents his principal argument: chromatic mediant relationships fall outside the purview of traditional tonal-theoretic approaches, and he wants to bring them in as a way to approach the repertoire of the nineteenth century. His view is that since dominant relations (essential to the tonal system) embody common-tone connections, then chromatic third-relations should be treated the same way. He suggests that tonic/chromatic-mediant

1 By necessity for his methodology (emphasis on function and root motion), Kopp leaves out reference to some of the literature dealing with nineteenth-century chromatic style in general. One thinks, for example, of William Benjamin (1975) or the so-called double-tonic complexes posited by Robert Bailey (1985). Moreover, little emphasis is given to linear techniques such as the often-used diatonic and chromatic 5-6. 